\title{
Correction to: Very preterm infants engage in an intervention to train their control of attention: results from the feasibility study of the attention control training (ACT) randomised trial
}

Oliver Perra ${ }^{1,2^{*}}$, Sam Wass ${ }^{3}$, Alison McNulty ${ }^{4}$, David Sweet ${ }^{5}$, Kostas A. Papageorgiou $^{6}$, Matthew Johnston ${ }^{1,2,6}$, Delfina Bilello ${ }^{1,2,6}$, Aaron Patterson ${ }^{6}$ and Fiona Alderdice ${ }^{7}$

Correction to: Pilot Feasibility Stud 7, 66 (2021)

https://doi.org/10.1186/s40814-021-00809-z

Following publication of the original article [1], the authors reported an omission in the list of authors, having failed to recognise Aaron Patterson for his contribution to data collection.

The original article [1] has been updated.
Reference

1. Perra O, Wass S, McNulty A, et al. Very preterm infants engage in an intervention to train their control of attention: results from the feasibility study of the attention control training (ACT) randomised trial. Pilot Feasibility Stud. 2021;7:66. https://doi.org/10.1186/s40814-021-00809-Z.

\begin{abstract}
Author details
${ }^{1}$ School of Nursing and Midwifery, Queen's University Belfast, Medical Biology Building, 97 Lisburn Road, Belfast BT9 7BL, UK. ${ }^{2}$ Centre for Evidence and Social Innovation, Queen's University Belfast, Medical Biology Centre, 97 Lisburn Road, Belfast BT9 7BL, Northern Ireland, UK. ${ }^{3}$ School of Psychology, University of East London, London, UK. ${ }^{4}$ TinyLife, The Premature Baby Charity for Northern Ireland, Belfast, Northern Ireland, UK. ${ }^{5}$ Health and Social Care Belfast Trust, Belfast, Northern Ireland, UK. ' 5 Chool of Psychology, Queen's University Belfast, Belfast, UK. ${ }^{7}$ Nuffield Department of Population Health, University of Oxford, Oxford, UK.
\end{abstract}

Published online: 11 November 2021

\section{1-00809-z}

\footnotetext{
*Correspondence: o.perra@qub.ac.uk
}

${ }^{2}$ Centre for Evidence and Social Innovation, Queen's University Belfast,

Medical Biology Centre, 97 Lisburn Road, Belfast BT9 7BL, Northern Ireland, UK

Full list of author information is available at the end of the article

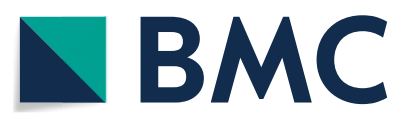

(c) The Author(s) 2021. Open Access This article is licensed under a Creative Commons Attribution 4.0 International License, which permits use, sharing, adaptation, distribution and reproduction in any medium or format, as long as you give appropriate credit to the original author(s) and the source, provide a link to the Creative Commons licence, and indicate if changes were made. The images or other third party material in this article are included in the article's Creative Commons licence, unless indicated otherwise in a credit line to the material. If material is not included in the article's Creative Commons licence and your intended use is not permitted by statutory regulation or exceeds the permitted use, you will need to obtain permission directly from the copyright holder. To view a copy of this licence, visit http://creativecommons.org/licenses/by/4.0/. The Creative Commons Public Domain Dedication waiver (http://creativeco mmons.org/publicdomain/zero/1.0/) applies to the data made available in this article, unless otherwise stated in a credit line to the data. 